J. Clin. Chem. Clin. Biochem.

Vol. 27, 1989, pp. 505-509

(C) 1989 Walter de Gruyter \& Co. Berlin - New York

\title{
A Sensitive and Wide-Scale Enzyme-Immunoassay for Human Transferrin
}

\author{
By Zemira Samra1), Tsilia Lazarovich
}

Department of Microbiology, Assaf Harofeh Medical Center, Zerifin and

David Sompolinsky

Rapoport Laboratory for Medical Microbiology, Bar Ilan University, Ramat Gan, Israel

(Received January 19/November 9, 1988//May 19, 1989)

Summary: We describe an ELISA technique for human transferrin. The test has a lowest detection limit of $2 \mu \mathrm{g} / \mathrm{l}$ and a wide range. It is specific for human transferrin and its reproducibility proved acceptable in both intra-run and between-day examinations. Results obtained by radial immunodiffusion and by ELISA were strongly correlated $(n=51 ; y=0.92 x+16.1 ; r=0.90)$. The cost in Israel for disposables and chemicals for triplicate examination is $\$ 0.55$ per sample. This is $7-8$ times less than the cost of a determination, using commercial immunodiffusion plates.

This assay is of particular value where the sample size is limited, e.g. samples of $1-4 \mu$ are sufficient for the determination of transferrin in tears. The transferrin concentrations in arterial and venous cord blood were shown to be essentially identical and similar to that in adult blood.

\section{Introduction}

It is well documented that a great number of pathological conditions may be associated with abnormal transferrin metabolism $(1=8)$. The need for sensitive methods for quantitation of transferrin in a great variety of samples (serum, semen (9), exocrine secretions (10), cell cultures (8)) is therefore increasing. The assays most commonly used at present (radial immunodiffusion, nephelometry and the iron capacity method) have low sensitivity, and the results from these different methods sometimes show a poor correlation $(11-12)$. We present an ELISA technique that is simple to perform and cost-effective, and which has a high sensitivity and specificity. The technique may be particularly useful for samples of restricted size (tears, blood from neonates) and/or of low concentration. An electronic literature search (Medline) has not retrieved any reference to the adaptation of ELISA techniques for transferrin (up to March 1987). 1) Present address: Department of Microbiology, Beilinson
Medical Center, Petah Tikva 49100, Israel.

\section{Materials and Methods}

Materials

Initially, two different standards were used: purified human transferrin (T3400, Sigma Ltd., St. Louis, USA) and human serum calibrated for transferrin level (Behringwerke AG, Marburg). Later, since the ELISA technique showed good agreement between the transferrin contents indicated by the manufacturers, only the Behringwerke standard was used routinely.

Affinity purified rabbit anti-human transferrin (Pharmacia Ltd., Uppsala, Sweden) was used in the ELISA both as catching and as detecting antibody. The portion used for detection was biotinylated with biotin N-hydroxy succinimide (13) in our laboratory. The biotinylated immunoglobulin is stable for at least 6 months. It is stored at $-20^{\circ} \mathrm{C}$ in $5 \mu \mathrm{l}$ portions and thawed only for use.

Alkaline phosphatase ${ }^{2}$ )-conjugated avidin, phosphatase substrate (4-nitrophenylphosphate disodium salt), various animal transferrins and agarose were products of Sigma Ltd.

\section{Radial immunodiffusion}

Anti-transferrin at $3 \mu \mathrm{l} / \mathrm{cm}^{2}$ was added to agarose $(10 \mathrm{~g} / \mathrm{l})$ in phosphate-buffered saline ( $\mathrm{pH}$ 7.2). Serum samples at a $1: 10$

\footnotetext{
2) Enzyme:

Alkaline phosphatase, orthophosphoric-monoester phosphohydrolase EC 3.1.3.1
} 
dilution were applied in a volume of $4 \mu \mathrm{l}$. After 24 hours at room temperature, the diffusion diameters were recorded for standard and unknown samples.

\section{ELISA procedure}

Wells of microtiter plates (M129B, Dynatech) were coated with anti-transferrin in tris-buffer (Tris (hydroxymethyl) aminomethane $1.21 \mathrm{~g} / \mathrm{l} ; \mathrm{NaCl} 5.84 \mathrm{~g} / \mathrm{l} ; \mathrm{pH} 8.5$ ) and stored at $4^{\circ} \mathrm{C}$ for up to 14 days. The actual analysis was performed on two subsequent days:

\section{First day}

1. Post-coating with $30 \mathrm{~g} / \mathrm{l}$ bovine serum albumin in tris-buffer.

2. Standard samples in a two-fold dilution gradient (2-4 wells for each dilution) and appropriately diluted clinical samples (3 wells for each) were incubated for 2 hours at room temperature. The dilutions were performed in phosphatebuffered saline $\left(\mathrm{NaCl} 29.2 \mathrm{~g} / \mathrm{l} ; \mathrm{KCl} 0.2 \mathrm{~g} / \mathrm{l} ; \mathrm{KH}_{2} \mathrm{PO}_{4} 0.2 \mathrm{~g} / \mathrm{l}\right.$; $\mathrm{Na}_{2} \mathrm{HPO}_{4} 1.2 \mathrm{~g} / \mathrm{l} ; \mathrm{pH} 7.2$ ) containing $10 \mathrm{~g} / 1$ bovine serum albumin.

3. Rinsing and application of the biotinylated anti-transferrin diluted $1: 10^{4}$ in phosphate-buffered saline containing $10 \mathrm{~g} / \mathrm{l}$ bovine serum albumin. Incubation for 2 hours at room temperature $\left(20^{\circ} \mathrm{C}\right)$ and overnight at $4^{\circ} \mathrm{C}$.

\section{Second day}

1. Rinsing and application of phosphatase-conjugated avidin (2300 U/1 of alkaline phosphatase; 2 mol of phosphatase per mol of avidin). Incubation for two hours at room temperature.

2. Rinsing and application of phosphatase substrate (4-nitrophenylphosphate disodium salt $1 \mathrm{~g} / \mathrm{l}$ in glycine buffer: glycine $7.5 \mathrm{~g} / \mathrm{l} ; \mathrm{ZnCl}_{2} 130 \mu \mathrm{g} / \mathrm{l} ; \mathrm{MgCl}_{2} 200 \mu \mathrm{g} / \mathrm{l} ; \mathrm{pH}$ 10.4), incubation at room temperature $\left(20^{\circ} \mathrm{C}\right), 120 \mathrm{~min}$.

3. Absorbance at $405 \mathrm{~nm}$ was recorded on a Flow Titertek Multiskan.

Results of unknown samples can be obtained either from a best-fit curve of absorption against log-concentration or, as in our routine, from a computerized log-logit SAS-program (Statistical Analysis System). The computer-generated least-squares curve was used to determine the reliable range of concentrations according to two criteria:

1. Maximal variations of less than $25 \%$ from the average absorbance obtained with multiple samples of a certain dilution;

2. essential linearity of the log-logit curve.

\section{Results}

\section{Detection limit and concentration range}

As seen in figure 1 , the reliable range of the assay is at least $2-128 \mu \mathrm{g} / \mathrm{l}$. This is wider than the range of variations of transferrin levels observed in most kinds of clinical specimens. Therefore, one dilution of the samples can be chosen so that virtually all of them will fall within the concentration range of the assay. In practice, we routinely diluted serum $1: 10^{5}$; amniotic fluid $2: 10^{4}$; tears from inflamed eyes $1: 10^{3}$ and tears from non-inflamed eyes $2: 10^{2}$. Figure 2 , based on sera from seven patients, shows a linear correlation between the degree of dilution and the measured concentration.

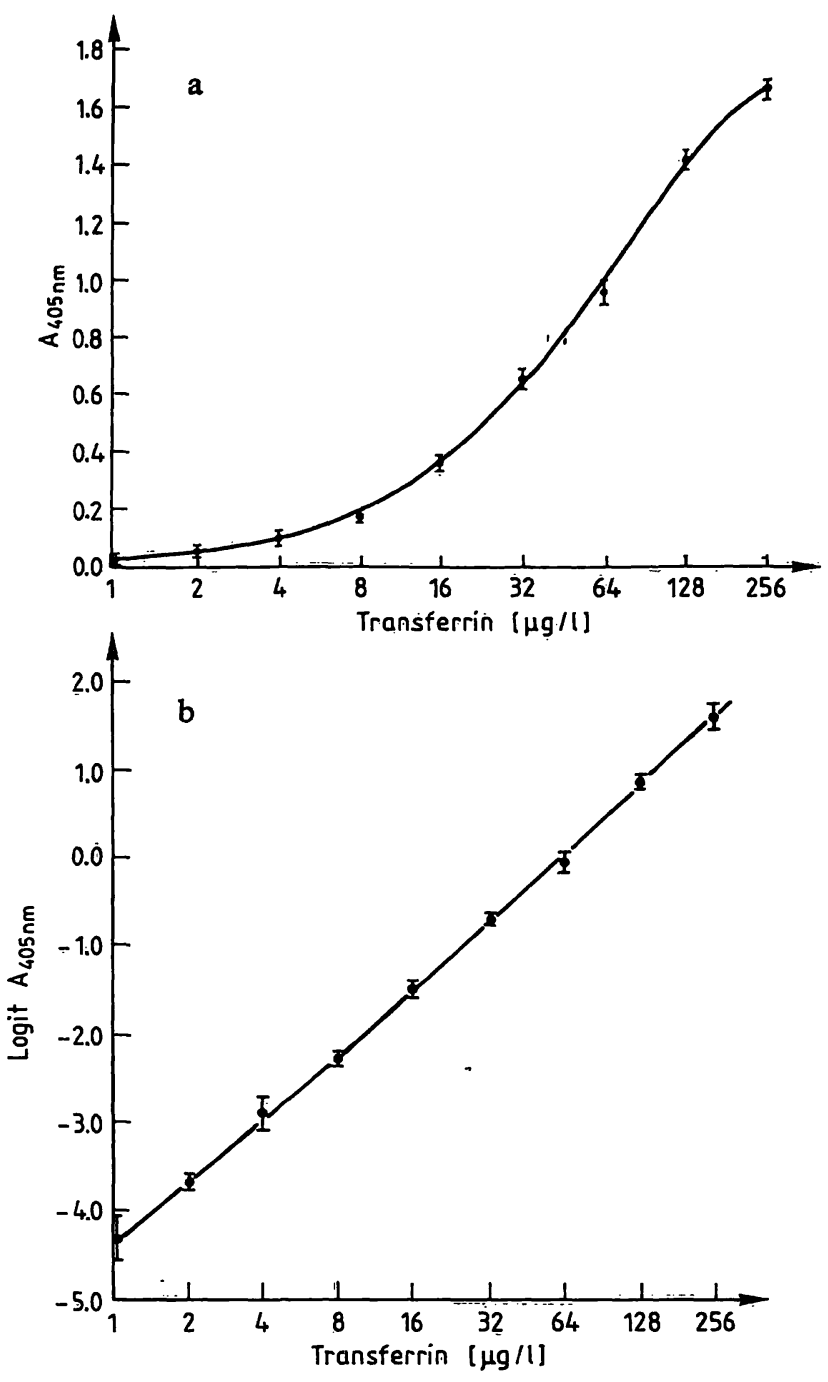

Fig. 1. Standard curve for ELISA of human transferrin. Abscissa: transferrin concentrations of a series of double dilutions of a commercial calibrated serum. Each dilution was assayed in quadruplicate.

Ordinate: $\mathrm{A}_{405 \mathrm{~nm}}$; mean and $\mathrm{SD}$ are indicated.

1a. Concentration versus $A_{405 \mathrm{~nm}}$.

1b. Concentration versus the logit $A_{405 \mathrm{~nm}}$.

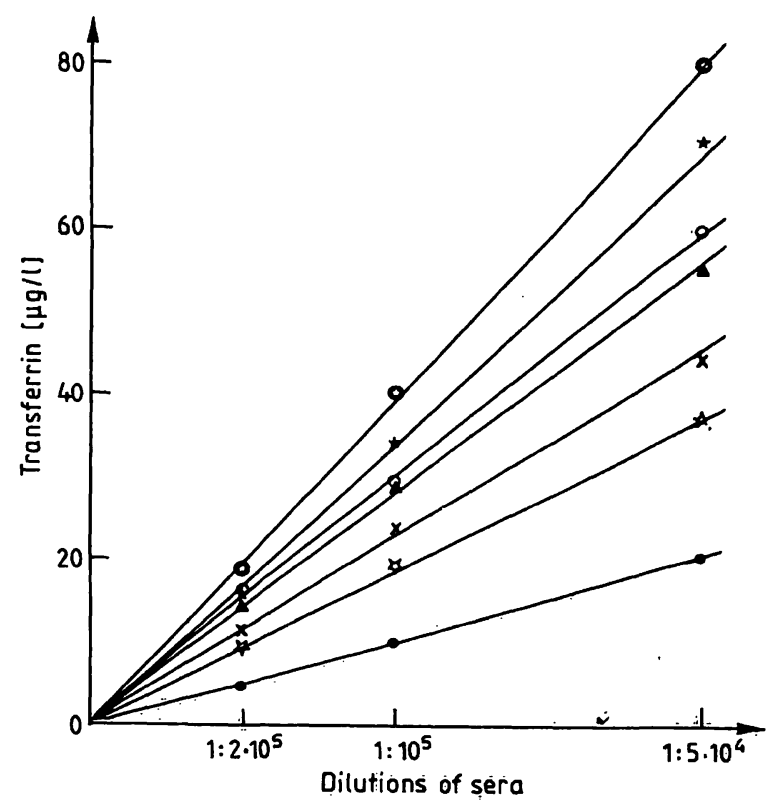

Fig. 2. Transferrin determination by ELISA with 7 sera diluted to different degrees. 


\section{Specificity}

In the assay the following proteins (all from Sigma Ltd.) gave spectrophotometric readings of $A_{405 \mathrm{~nm}}$ $<0.09$ : Ferritin (final concentration $1 \mathrm{mg} / 1$ ); lactoferrin $(50 \mathrm{mg} / 1)$; bovine transferrin $(50 \mathrm{mg} / \mathrm{l})$; equine transferrin $(50 \mathrm{mg} / \mathrm{l})$; and rabbit transferrin $(50 \mathrm{mg} / \mathrm{l})$. The specificity of the anti-transferrin was confirmed in double immunodiffusion assays with human, bovine and equine transferrin (details not shown).

Transferrin concentrations assessed by ELISA and radial immunodiffusion

Figure 3 compares the transferrin concentrations of 51 serum specimens assessed by radial immunodiffusion (RID) and by ELISA. The least-squares line was $y=0.92 x+16.1$ and the correlation coefficient $r=0.90$. The sera were diluted $1: 10$ for RID and $1: 10^{5}$ for ELISA.

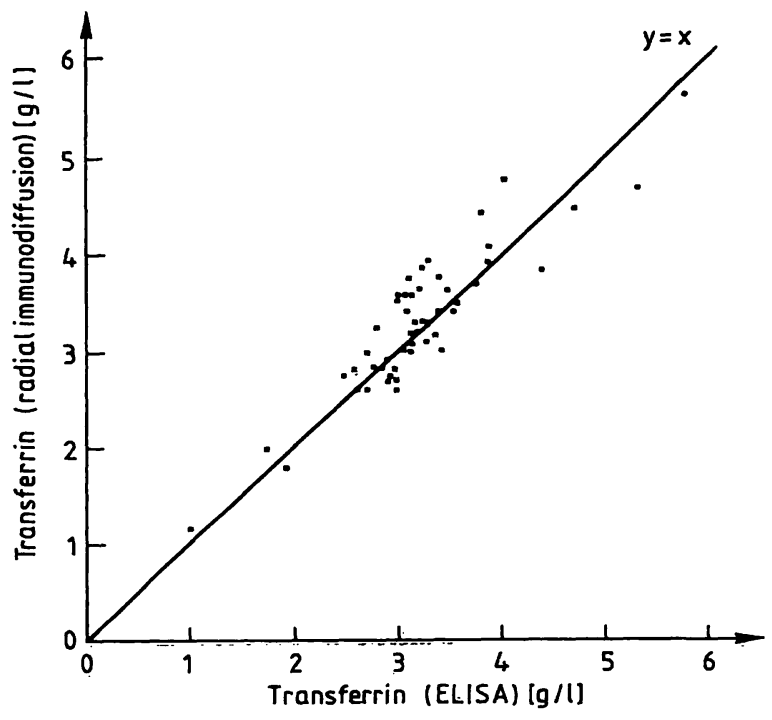

Fig. 3. Comparison between transferrin concentrations $(g / 1)$ of 51 serum samples assessed by radial immunodiffusion (RID) and ELISA.

The least-squares line was $y=0.92 x+16.1$. The correlation coefficient $\mathrm{r}=0.90$.

\section{Reproducibility}

Table 1 shows an intra-run variance of about $7 \%$ for sample dilutions assayed at final concentrations of 14 and $28 \mu \mathrm{g} / 1$ and of $13-16 \%$ for final concentrations of 55 and $127 \mu \mathrm{g} / \mathrm{l}$. Analysis of samples in triplicate, in 10 different runs showed a day-to-day variance of $<10 \%$ for low and moderately high concentrations, and $15 \%$ for high concentrations (tab. 2).
Tab. 1. Intra-assay variance of transferrin determination by ELISA.

A serum sample was diluted to give 4 different final concentrations. Each of the diluted samples was assayed in 20 wells of a microtiter plate.

\begin{tabular}{lcc}
\hline $\begin{array}{l}\text { Sample } \\
\text { No. }\end{array}$ & $\begin{array}{l}\text { Transferrin } \\
(\mu \mathrm{g} / \mathrm{l})\end{array}$ & $\begin{array}{l}\text { CV } \\
(\%)\end{array}$ \\
\hline 1 & 14.1 & 7.0 \\
2 & 27.6 & 7.5 \\
3 & 55.3 & 16.1 \\
4 & 127.3 & 13.3 \\
\hline
\end{tabular}

Tab. 2. Inter-assay variance of transferrin determination by ELISA.

The samples were examined on 10 different days, each time in triplicate.

\begin{tabular}{lll}
\hline $\begin{array}{l}\text { Sample } \\
\text { No. }\end{array}$ & $\begin{array}{l}\text { Transferrin } \\
(\mu \mathrm{g} / \mathrm{l}) \\
\text { Mean of all } \\
\text { determinations }\end{array}$ & $\begin{array}{l}\text { Day to day } \\
\text { CV }(\%) \\
\text { of the mean }\end{array}$ \\
\hline 1 & 15.8 & \\
2 & 28.6 & 6.2 \\
3 & 55.4 & 9.8 \\
4 & 128.0 & 9.1 \\
\hline
\end{tabular}

\section{Some practical applications}

A. Dissanayake \& deSilva (14) have found that the serum transferrin concentrations of neonates were about $35 \%$ of normal adult levels. This stimulated us to try to calculate the possible transplacental transfer of maternal transferrin by using the difference between the concentrations in venous and arterial cord blood. However, for 10 neonates examined, the transferrin concentrations of venous and arterial cord blood were comparable and not distinct from adult levels (tab. 3). We have no explanation for the discrepancy with the results of the above-mentioned study (14). The transferrin concentration of amniotic fluid was $189.4 \pm 66.1 \mathrm{mg} / \mathrm{l}$.

B. Some plasma proteins can be used as markers for the leakage of macromolecules from the circulation to mucous membranes, e.g. as a measure of the intensity of inflammation or in immunological studies (15). A marker protein must be one that is not synthesized by cells of the mucous membrane. Both albumin (16) and transferrin (10) have been used as marker proteins for tears. Both groups of investigators used RID to quantitate their marker proteins. It has been claimed that transferrin is absent from tears of healthy eyes (17-19). However, by the ELISA technique, all the tear samples examined were shown to contain transferrin, with concentration ranges of $0.2-14 \mathrm{mg} / \mathrm{l}$ (mean $=4.3 \mathrm{mg} / \mathrm{l})$ in healthy controls 
Tab. 3. Transferrin concentrations of arterial and venous cord blood and amniotic fluid from 10 full-term neonates.

\begin{tabular}{|c|c|c|c|c|}
\hline & \multirow[t]{2}{*}{$\mathbf{n}$} & \multicolumn{3}{|l|}{$\begin{array}{l}\text { Transferrin } \\
x \pm s\end{array}$} \\
\hline & & $(\mathrm{mg} / \mathrm{l})$ & $r(p)$ & $t^{\mathbf{a}}(p)$ \\
\hline $\begin{array}{l}\text { Arterial cord blood } \\
\text { Venous cord blood } \\
\text { Amniotic fluid }\end{array}$ & $\begin{array}{l}10 \\
10 \\
10\end{array}$ & $\begin{array}{l}2263 \pm 496 \\
2174 \pm 708 \\
189.4 \pm 66.1\end{array}$ & $\begin{aligned} 0.94 & (<0.001) \\
-0.14 & (>0.1)\end{aligned}$ & $\therefore 0.95(>0.1)$ \\
\hline
\end{tabular}

a paired t-test

Tab. 4. Concentration of transferrin in tear fluid and serum of vernal conjunctivitis patients and healthy controls.

\begin{tabular}{|c|c|c|c|c|c|}
\hline & \multicolumn{2}{|c|}{ Tear fluid } & \multicolumn{2}{|c|}{ Serum } & \multirow{2}{*}{$\begin{array}{l}\text { Ratio } \\
\overline{\mathbf{x}}_{2} / \overline{\mathbf{x}}_{\mathbf{s}}\end{array}$} \\
\hline & $\bar{n}$ & $\dot{\bar{x}}_{\mathrm{t}} \pm \mathrm{s}(\mathrm{mg} / \mathrm{l})$ & $\bar{n}$ & $\overline{\mathrm{x}}_{\mathrm{s}} \pm \mathrm{s}(\mathrm{mg} / \mathrm{l})$ & \\
\hline $\begin{array}{l}\text { Controls } \\
\text { Vernal conjunctivitis }\end{array}$ & $\begin{array}{l}15 \\
22\end{array}$ & $\begin{array}{r}4.3 \pm 4.7 \\
108 \pm 76.1\end{array}$ & $\begin{array}{r}8 \\
11\end{array}$ & $\begin{array}{l}2133 \pm 527 \\
2358 \pm 1073\end{array}$ & $\begin{array}{l}0.002 \\
0.046\end{array}$ \\
\hline
\end{tabular}

The differences between transferrin concentrations for patients and healthy controls were tested for significance by unpaired $t-$ test.

For tears: $\mathrm{t}=5.28 ; \mathrm{df}=35 ; \mathrm{p}<0.0005$

For serum: $t=0.44 ; \mathrm{df}=17$; $\mathrm{p}: 0.30-0.35$

and $10-270 \mathrm{mg} / \mathrm{l}($ mean $=108 \mathrm{mg} / \mathrm{l})$ in patients with inflamed eyes (tab. 4). Table 5 compares the transudation coefficients of tears calculated from serum albumin (RID) and transferrin (ELISA) concentrations of tears and serum. Considering the differences between the techniques used, the agreement between the results is satisfactory.

\section{Discussion}

The role of transferrin in a wide range of pathological conditions must be determined with the aid of new sensitive and wide-range assays for this protein. By using anti-transferrin labeled with biotin, we were able to develop an ELISA technique for transferrin, using a single monospecific commercial rabbit antibody.

The test is of particular value for the analysis of clinical samples that are available only in very small amounts (e. g. tears) and are often destined for a large battery of tests. In terms of sensitivity and the width of the concentration range, the assay is comparable with, or even better than, the recently described radioimmunoassay (20) and luminescence immunoassay (21) for transferrin. Precision was a little less than for the chemiluminescent method (21) but comparable with the results of the RIA (20).

This ELISA test is very cost effective, at least in Israel. The direct costs for disposables and immunochemicals
Tab. 5. Transudation coefficients (tear/blood levels) assessed from serum albumin and transferrin separately for tears of 9 vernal conjunctivitis patients.

\begin{tabular}{lllll}
\hline $\begin{array}{lllll}\text { Patient } \\
\text { No. }\end{array}$ & \multicolumn{2}{l}{ Right Eye } & & \multicolumn{2}{l}{ Left Eye } \\
& Albumin & Transferrin & Albumin & Transferrin \\
\hline 1 & 0.01 & 0.01 & 0.03 & 0.02 \\
2 & 0.04 & 0.04 & 0.03 & 0.03 \\
3 & 0.04 & 0.03 & 0.03 & 0.02 \\
4 & 0.09 & 0.07 & 0.08 & 0.05 \\
5 & 0.06 & 0.04 & 0.09 & 0.08 \\
6 & 0.05 & 0.05 & 0.06 & 0.07 \\
7 & 0.14 & 0.16 & 0.08 & 0.12 \\
8 & 0.06 & 0.05 & 0.09 & 0.09 \\
9 & 0.05 & 0.05 & 0.02 & 0.01 \\
\hline
\end{tabular}

For albumin transudation coefficient $(n=18): \bar{x} \pm s=0.06$ $\pm 0.03$

For transferrin, $\bar{x} \pm s=0.06 \pm 0.04$

Correlation coefficient $r=0.92, p<0.001$

are $\$ 0.55$ per sample tested in triplicate. The working time for a load of 20 samples (in triplicate) is $150 \mathrm{~min}$ on the first day and $90 \mathrm{~min}$ on the second day of the assay, or $12 \mathrm{~min}$ per test. A commercial agar plate for RID for transferrin costs about $\$ 50$ for 12 samples, i. e. more than $\$ 4$ per test.

The ELISA technique can easily be performed in one day. A two-day programme is, however, more convenient for laboratory technicians, who also perform a wide range of other duties. 


\section{References}

1. Morgan, E. H. (1981) Mol. Aspects Med. 4, 1-123.

2. Washaw, B. L., Check, I. J., Hymes, L. C. \& DiRusso, S. C. (1984) Clin. Immunol. Immunopathol. 33, 210-219.

3. Hunter, R. L., Bennett, B., Garrison, C., Winton, E. F. \& Vogler, W. R. (1984) Am. J. Clin. Pathol. 81, 581-585; 81, $748-753$.

4. Huebers, H. A. \& Finch, C. A. (1984) Blood 64, 763- 767.

5. Aisen, P. (1984) Semin. Liver Dis. 4, 193-206.

6. Dilena, B. A. \& Peake, M. J. (1986) J. Clin. Chem. Clin. Biochem. 24, 735-740.

7. Sueldo, C., Marrow, R. P., Berger, T., Kletzky, O. A. \& O'Brien, J. (1984) Amer. J. Obstet. Gynecol. 150, 528530.

8. Holmes, S. D., Lipshultz, L. I. \& Smith, R. G. (1984) J. Clin. Endocrinol. Metab. 59, 1058-1062.

9. Caldini, A. L., Orlando, C., Messeri, G., Pazzagli, M., Baldi, E. \& Serio, M. (1986) Clin. Chem. 32, 153-156.

10. Ballow, M., Donshik, P. C. \& Mendelson, L. (1985) J. Allergy Clin. Immunol. 76, 473-476.

11. Altounian, A. (1978) Can. J. Med. Technol. 40, D36-D42.
12. Kreutzer, H. J. H. (1976) J. Clin. Chem. Clin. Biochem. $14,401-406$.

13. Adler-Storthz, K., Dressman, G. R., Graham, D. Y. \& Evans, D. G. (1985) J. Immunoassay 6, 67-77.

14. Dissanayake, S. \& deSilva, L. V. K. (1984) J. Trop. Med. Hyg. 87, 167-171.

15. Deuschl, H. \& Johansson, S. G. O. (1974) Clin. Exp. Immunol. 16, $401-412$.

16. Samra, Z., Zavaro, A., Barishak, Y. \& Sompolinsky, D. (1984) Int. Archs. Allergy Appl. Immun. 74, 158-164.

17. Ballow, M., Donshik, P. C., Mendelson, L., Rapacz, P. \& Sparks, K. (1983) Amer. J. Ophthalmol. 95, 161-168.

18. Van Haeringen, N. J. (1981) Surv. Ophthalmol. 26, 84-96.

19. Josephson, A. S. \& Weiner, R. A. (1968) J. Immunol. 100, 1080-1092.

20. Broehlugse, R. M. (1974) Invest. Ophthalmol. 13, 556561.

21. Anderson, G. J., Mackerras, A., Mack, U., Powell, L. W. \& Halliday, J. W. (1986) J. Lab. Clin. Med. 107, 59-65.

Prof. Dr. David Sompolinsky

Rapoport Laboratory

for Medical Microbiology

Bar Ilan University

Ramat Gan 52100

Israel 
,

.

$-$ 